\title{
First Report of Septoria Leaf Spot on Marigold (Tagetes erecta L.) from Himachal Pradesh, India
}

\author{
Arti Shukla* and Rajesh Thakur
}

Krishi Vigyan Kendra, Kandaghat, Dr. Y.S. Parmar University of Horticulture and Forestry, Nauni, Solan 173 230, Himachal Pradesh, India

*Corresponding author

A B S T R A C T

\begin{abstract}
Marigold, a member of the Asteraceae family is one of the five most commonly cultivated and used flower in urban and rural India for decorations and religious functions. The

Key words

Marigold, Tagetus erecta, Septoria species

\section{Article Info}

Accepted:

14 December 2017

Available Online:

10 January 2018 leaves and flowers possess medicinal value having phenolics and antioxidants. Although these plants are relatively easy to grow, but are susceptible to many fungal and bacterial diseases. During the year 2016, African marigold (Tegetes erecta L.) plants grown at KVK Kandaghat were found infected with a leaf spotting fungus i.e. Septoria $\mathrm{sp}$. in the months of July-August. The initial symptoms are small, water-soaked circular spots on older leaves. The centers of these spots gradually turn gray to tan and have dark brown margins. The severity of the disease ranged from 30-70 per cent in marigold growing areas of the district and under favourable environmental conditions may go upto 100 per cent. During microscopic examination, dark, globose, ostiolate and erumpent pycnidia were observed. The conidia were hyaline, narrowly elongate to filiform, measuring $25.2-48.7 \mu$ in length and 1.04 to $2.98 \mu$ in breadth with an average of $39.2 \times 2.0 \mu$ under $400 \mathrm{x}$ magnification. The associated pathogen was isolated in pure form. The colonies were initially white, later on develop slight brown tinge with irregular margins.
\end{abstract}

\section{Introduction}

Marigold, a member of the Asteraceae family is used as a bedding plant or can be kept indoors as a houseplant and constitutes as one of the five most commonly cultivated and used flower in urban and rural India for decorations and religious functions. It is a native of Mexico and South America and was introduced in India from Portugal in $16^{\text {th }}$ century. Out of the 33 species of marigold, Mexican marigold commonly called African marigold (Tagetus erecta) and French marigold (T. patula) are the ones most commonly cultivated in India. The crop is grown throughout the country.

Maximum acreage under this crop is occupied by Madhya Pradesh while, Himachal ranks $9^{\text {th }}$ in area and production of marigold. The crop occupies an area of 179.25 ha with annual production of 15,774 MT in the state. The crop is also gaining importance in mid hills of Himachal Pradesh and in district Solan, it is grown over an area of 9.76 ha with annual production of 102.53 MT. 
Marigold is extensively used for making garlands, beautification and other purposes i.e. pigment and oil extraction and therapeutic use. The leaves and flowers possess medicinal value having phenolics and antioxidants therefore, are in great demand in pharmaceutical industry (Tripathy and Gupta, 1991; Khalil et al., 2007). Marigold (Tegetes erecta) may help protect certain crop plants from nematode pests when planted in fields (Olabiyi and Oyedunmade, 2007). It is most effective against the nematode species Pratylenchus penetrans. The ray florets have been used in lettuce salads and other foods to add colour and flavour. The flowers are rich in carotenoids, and are thus used to make food and feed pigments. The dried flower petals, ground to a powder, are used in poultry feed to ensure a good colouration of egg yolks and broiler skin, especially in the absence of wellpigmented yellow maize in the feed.

Although these plants are relatively easy to grow, but are susceptible to many fungal and bacterial diseases which reduce the qualitative and quantitative yield of the flowers. During the year 2016, African marigold (Tegetes erecta L.) plants grown at KVK Kandaghat were found infected with a leaf spotting fungus i.e. Septoria sp. in the months of JulyAugust.

\section{Symptoms}

Symptoms commonly develop on leaves, but can occur on petioles, stems, and the calyx also. The initial symptoms are small, watersoaked circular spots on older leaves. The centers of these spots gradually turn gray to tan and have dark brown margins (Fig. 1). As the spots age, they sometimes enlarge and coalesce. The spots have dark brown, tiny dot like structures called pycnidia (fruiting bodies of the fungus) that are readily visible in the tan centers of the spots.

When spots are numerous, affected leaves turn yellow and eventually shrivel up, brown, and drop off (Fig. 2). Defoliation usually starts on the oldest leaves and can quickly spread progressively up the plant towards the new growth. The severity of the disease ranged from 30-70 per cent in marigold growing areas of the district and under favourable environmental conditions may go upto 100 per cent.

Fig.1 Symptoms of septoria leaf spot on marigold leaves. Fig.2 Completely infected plant
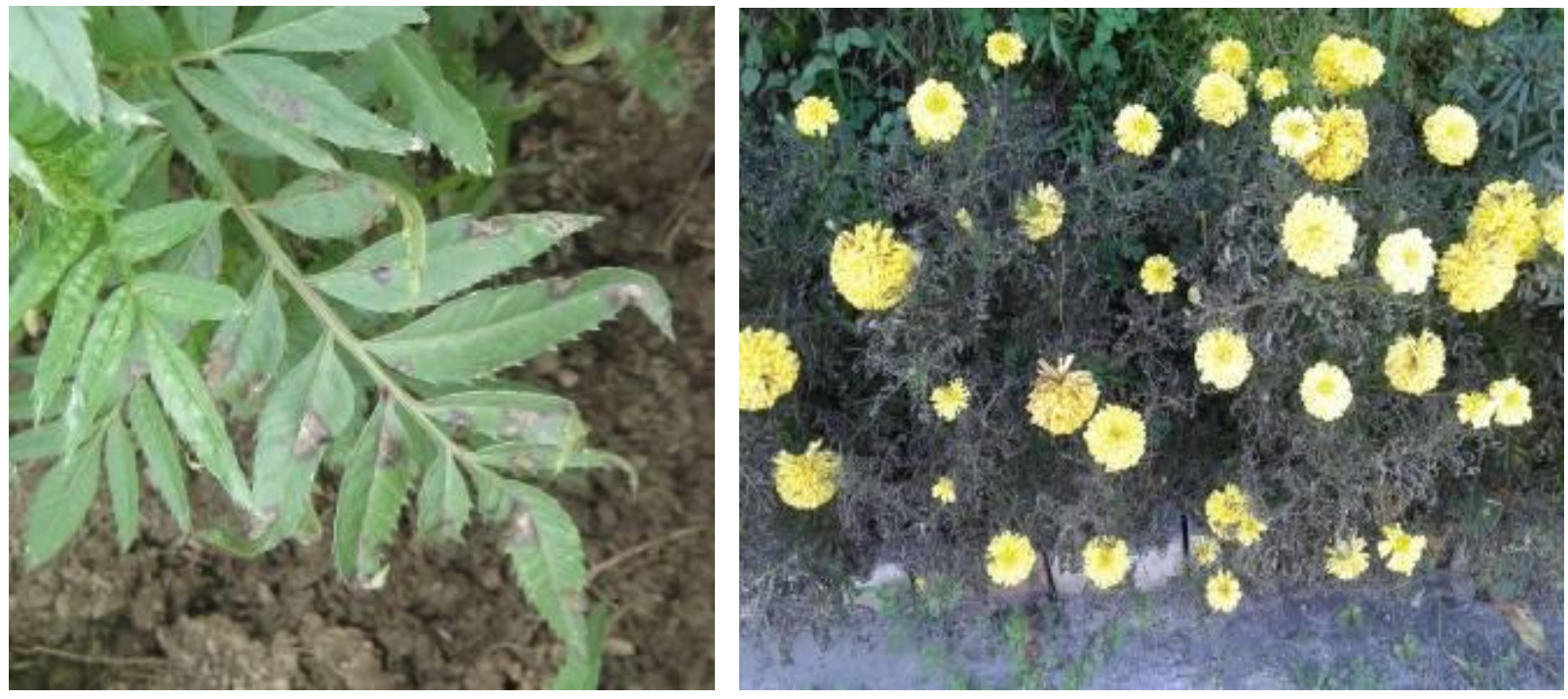
Fig.3 Conidia arising out of pycnidium embedded in leaf tissues

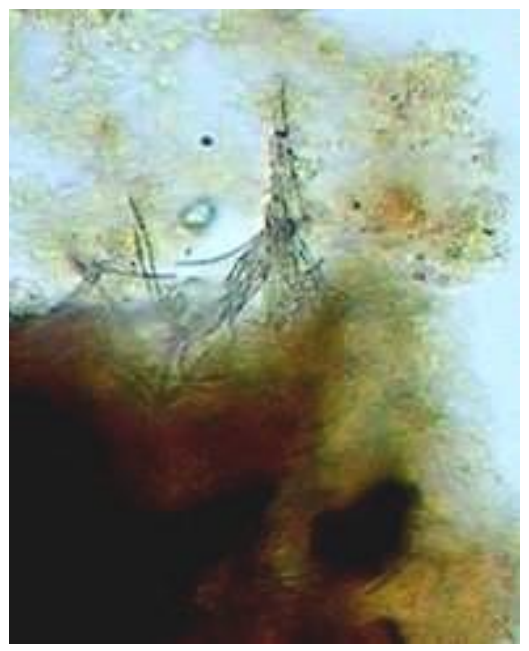

Fig.4 Conidia of Septoria sp. from leaves (x 400). Fig.5 Single conidium (x 400)
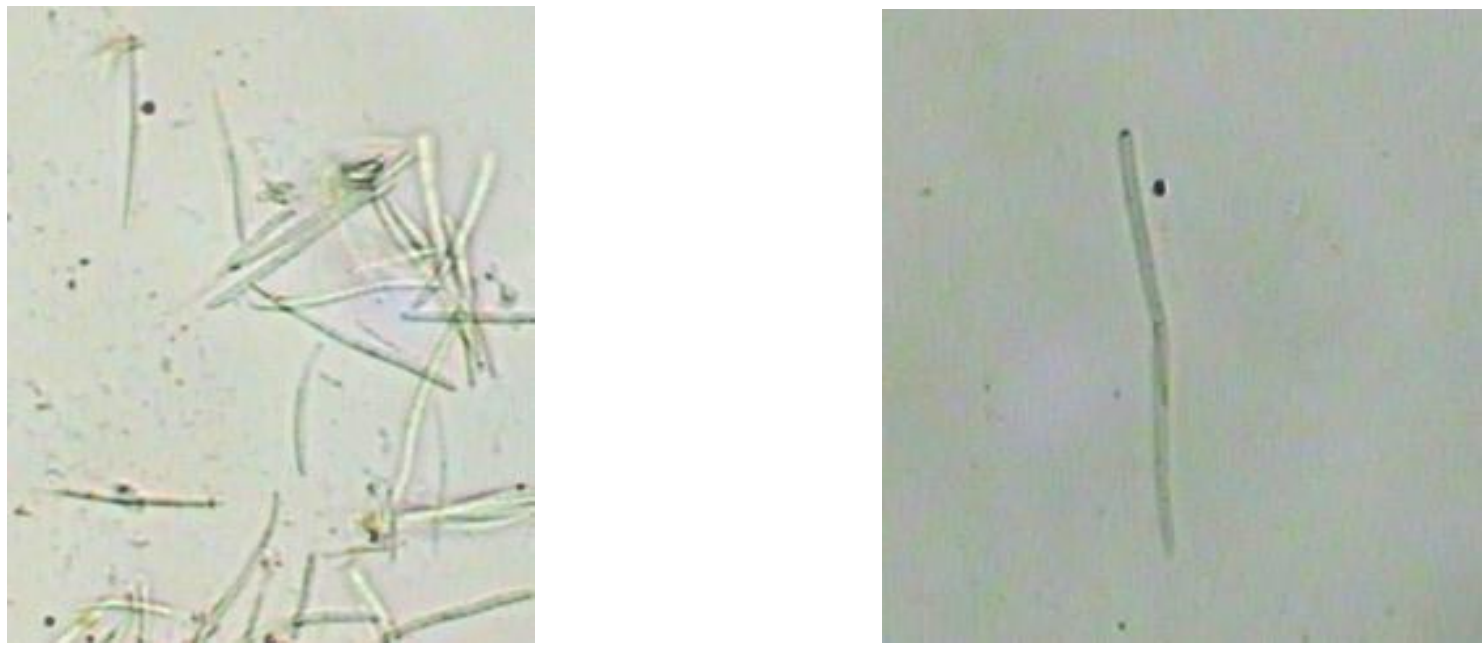

Fig.6 7 days old culture of Septoria on PDA

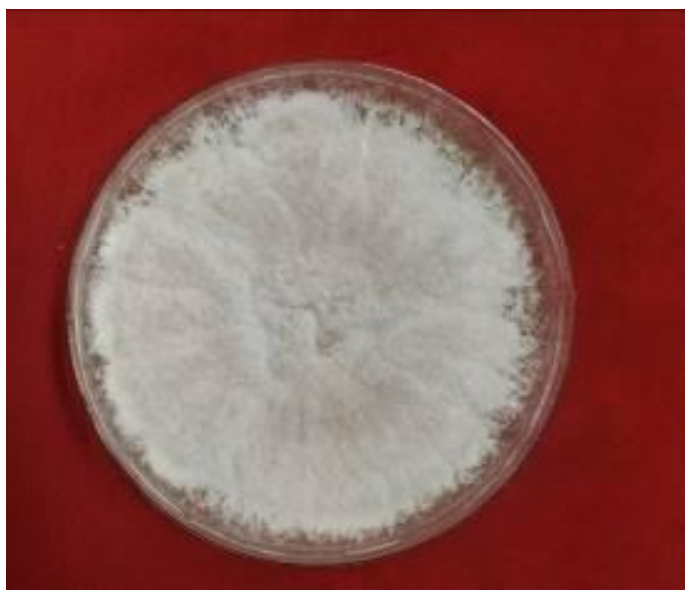


Fig.7 Mycelium of Septoria (x 200)

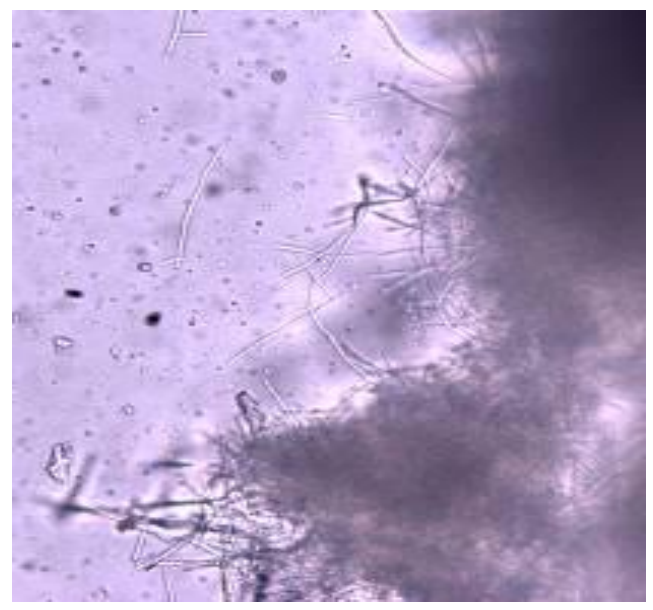

\section{Pathogen}

The samples were brought to the laboratory for further investigation. Slides were prepared using sterile distilled water. Images of micromorphological structures were captured under an Olympus Research Microscope (Model BX43) with QImaging CCD Camera (Model Retiga R1). During microscopic examination, dark, globose, ostiolate and erumpent pycnidia were observed and conidia were seen arising out of the pycnidium (Fig. $3)$. The pycniospores or conidia were hyaline, narrowly elongate to filiform with pointed or rounded ends.

The measurement of conidia was done using Magnus Pro Image Analysis Software, obtaining the average of 20 measurements. The conidia were $25.2-48.7 \mu$ in length and 1.04 to $2.98 \mu$ in breadth with an average of $39.2 \times 2.0 \mu$ under $400 \times$ magnification (Fig. 4 and 5). The associated fungus was isolated in pure form on PDA using standard practices. The colonies were initially white later on develop slight brown tinge with irregular margins (Fig. 6). The mycelium was hyaline and branched (Fig. 7). Sporulation occurred in 4 days old culture. The conidia were flexuous and hyaline (Fig. 8). On the basis of symptoms and spores morphology, the fungus
Fig.8 Conidia in culture (x200)

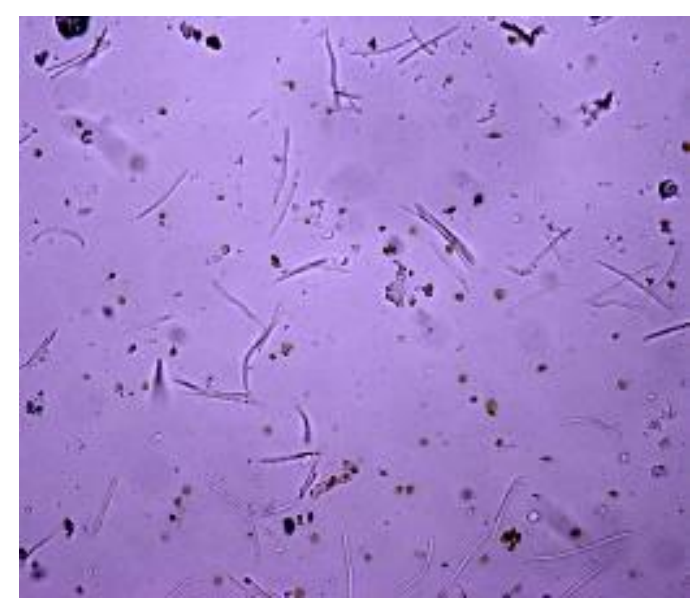

was identified as Septoria (Barnett, 1962, Bilgrami et al., 1991).

Septoria leaf spot is of common occurrence on chrysanthemum (Waddell, 1959; Magie and Overman, 1960, Chandel and Chandel, 2010) worldwide, however, the disease has not been reported on marigold from India so far. Although, it has been reported from Florida (Changsri, 1958) earlier however, this constitutes the first report of Septoria species on marigold from Himachal Pradesh, India.

\section{References}

Barnett, H.L., 1962. Illustrated genera of Imperfect fungi. Burgess Publishing Company, 426 S. Sixth Street, Minneapolis 15, Minn., pp. 225.

Bilgrami, K.S., Jamaluddin and Rizwi, M.A. 1991. Fungi of India. Part III (List and References). Today and Tomorrow's Printer and Publishers, New Delhi, 798p.

Chandel, S., and Chandel, V. 2010. Correlation of disease with meteorological factors and management of Septoria leaf spot of chrysanthemum (Chrysanthemum grandiflorum L.). Indian Journal of Agricultural Sciences. 80(1): 54-58. 
Changsri, W., 1958. Septoria leaf spot of marigold, Tagetes erecta, caused by Septoria tageticola. In: M.S. Thesis, University of Florida, 1958. 128p.

Khalil M.Y., Moustafa A.A., and Naquib N.Y. 2007. Growth, phenolic compounds and antioxidant activity of some medicinal plants grown under organic farming conditions. World Journal of Agriculture Science. 3: 451457.

Magie, R. O., and Overman, A. J. 1966. Chrysanthemum diseases in Florida. Univ. Fla. Agr. Exp. Sta. Bull. 637A. 49 p.
Olabiyi, T. I., and Oyedunmade, E. E. A. 2007. "Marigold (Tagetes erecta L.) as interplant with cowpea for the control of nematode pests" (PDF). African Crop Science Conference Proceedings. 8: 1075-1078.

Tripathy, A.K., and Gupta, KK. 1991. Plant phenolics of Tegetes erecta. Fitoterpia. 62(1): 91-92.

Waddell, H. T., 1959. Parasitism of Septoria obesa Syd. and S. chrysanthemella Sacc. on the cultivated Chrysanthemum. Ph.D. Thesis. Univ. Fla., Gainesville. 83 p.

\section{How to cite this article:}

Arti Shukla and Rajesh Thakur. 2018. First Report of Septoria Leaf Spot on Marigold (Tagetes erecta L.) from Himachal Pradesh, India. Int.J.Curr.Microbiol.App.Sci. 7(01): 1744-1748. doi: https://doi.org/10.20546/ijcmas.2018.701.211 